Leszek Kusak

Uniwersytet Ekonomiczny w Krakowie

e-mail: kusakl@uek.krakow.pl

\title{
O antropologii filozoficznej w ujęciu historycznym (rozważania na marginesie koncepcji Kanta i Herdera)
}

DOI: http://dx.doi.org/10.12775/RF.2017.021

\section{Uwagi wstępne}

Program antropologii filozoficznej, sformułowany na początku XX wieku przez Maxa Schelera, wzbudził duże zainteresowanie, nie zyskał jednak powszechnego uznania. Nawet wśród zwolenników nowej dyscypliny filozofii widoczne były różnice zdań, dotyczące jej założeń, metody oraz celu badań. W rezultacie antropologia filozoficzna nie tylko nie zmonopolizowała współczesnej refleksji nad człowiekiem, lecz także nie zajęła wyróżnionej pozycji w długim szeregu szkół, nurtów i sposobów myślenia o człowieku.

Filozoficzne dyskusje dotyczące różnych aspektów ludzkiej egzystencji toczą się od starożytności. Rzadko prowadzą jednak do konkluzywnych rozstrzygnięć. Współczesna sytuacja pod wieloma względami przypomina opisywany przez Schelera kryzys z przełomu XIX i XX wieku: rezultaty nauk empirycznych zajmujących się człowiekiem budzą uznanie, dysponujemy głębszym poznaniem i wiemy znacznie więcej niż poprzednie pokolenia. Nie dysponujemy jednak spójną i całościową koncepcją człowieka. Nasza wiedza jest bardzo rozproszona. Dzisiaj również możemy z czystym sumieniem powiedzieć: „człowiek stał się problematyczny". 
Dynamiczny rozwój nauk szczegółowych o człowieku sprawił, że już tylko pasjonatów "prehistorii” nauk empirycznych interesują traktaty Hipokratesa z Kos (460-377 r. p.n.e.) czy też Claudiusa Galenusa zwanego Galenem (130-200 r. n.e.). W dziedzinie filozoficznej refleksji nad człowiekiem sytuacja wygląda jednak inaczej - w niej Arystoteles i Kant mają wciąż coś do powiedzenia. Odwoływanie się do przeszłości, przypominanie wybranych koncepcji i kategorii, nadawanie im nowego sensu, w pewnym znaczeniu - przywracanie ich do życia, jest w filozofii powszechnie stosowaną praktyką. W tym duchu utrzymana jest również przedstawiona tu praca. Przypomina ona o zasługach Kanta i Herdera dla rozwoju antropologii filozoficznej i wskazuje na możliwość (potrzebę) ponownego wykorzystania idei, które w koncepcjach obu filozofów odgrywały ważną rolę, dzisiaj zaś pozostają zapomniane.

\section{Immanuel Kant - poszukiwanie drogi do antropologii (filozoficznej)}

Obecność Immanuela Kanta w podręcznikach historii antropologii filozoficznej nie budzi raczej wątpliwości. Jest on autorem słynnych czterech pytań, które w nowym świetle postawiły problem człowieka. W Logice Kant formułuje je następująco:

„Dziedzina filozofii [...] daje się rozparcelować na następujące pytania: 1) Co mogę wiedzieć? 2) Co powinienem czynić? 3) Na co wolno mi mieć nadzieję? 4) Czym jest człowiek? Na pierwsze pytanie odpowiada metafizyka, na drugie nauka o moralności, na trzecie religia, a na czwarte antropologia. W gruncie rzeczy wszystko to można by jednak zaliczyć do antropologii, gdyż trzy pierwsze pytania odnoszą się do ostatniego"1.

W wypowiedzi tej Kant rozstrzyga ważne kwestie. Po pierwsze: pytanie „czym jest człowiek?”, czyli klasyczne pytanie o istotę - według niego - stanowi fundament antropologii (pragmatycznej), nowożytną wersję pytania o arche. Po drugie: wszystkie inne dyscypliny filozofii, w pewnym sensie, odgrywają "służebną" rolę wobec antropologii - ich rezultaty umożliwiają bowiem samookreślenie i samopoznanie człowieka, prowadzą do odpowiedzi na pytanie "was ist der Mensch?".

W liście z maja 1793 roku do teologa C. G. Stäudlina ${ }^{2}$ Kant informuje adresata, że od ponad dwudziestu lat prowadzi wykłady z antropologii, które mają dać odpowiedź na pytanie „czym jest człowiek?”. Inaczej niż w Krytykach, które odwołują się do poznania apriorycznego, wykłady te

1 I. Kant, Logika. Podręcznik do wykładów, przeł. A. Banaszkiewicz, słowo/obraz terytoria, Gdańsk 2005, s. 37.

2 Zob. R. Brandt, Kommentar zu Kants Anthropologie, „Kant-Forschungen“, Bd. 10, Felix Meiner Verlag, Hamburg 1999, s. 16. 
prezentują człowieka widzianego przez pryzmat potocznego, empirycznego doświadczenia. Kant mówi w nich o funkcjonowaniu zmysłów, o marzeniach sennych, o słabościach i chorobach duszy, o przyjemnościach zmysłowych, namiętnościach i afektach, wzbogacając swoje wywody licznymi anegdotami i przykładami z życia codziennego ${ }^{3}$.

Wykłady z antropologii zostały opublikowane w 1798 roku, u schyłku życia Kanta. Pracę zatytułowaną Anthropologie in pragmatischer Hinsicht przyjęto chłodno4. Późniejsza recepcja dzieł Kanta sytuacji tej nie zmieniła.

Choć Antropologia w ujęciu pragmatycznym nie należy do najważniejszych dzieł Kanta, to jednak zawiera idee i argumenty, które odegrały rolę w historii nowoczesnej refleksji nad człowiekiem. Kant wyróżnia w niej dwa rodzaje antropologii: fizjologiczną i pragmatyczną. „Fizjologiczne poznanie człowieka jest zbadaniem tego, czym czyni człowieka przyroda (Natur), natomiast poznanie pragmatyczne bada, czym on sam jako istota działająca w sposób wolny siebie czyni lub też może i winien siebie uczynić" ${ }^{5}$.

Antropologia fizjologiczna ma charakter opisowy, zajmuje się budową i funkcjonowaniem ludzkiego ciała. Według Kanta jej zagadnienia wchodzą w zakres nauk szczegółowych (takich jak biologia, anatomia czy fizjologia), a nie filozofii. Antropologia pragmatyczna próbuje odpowiedzieć na ważniejsze, z filozoficznego punktu widzenia, pytanie: czym człowiek jako istota wolna może i powinien siebie uczynić? Ze względu na charakter i wagę tego pytania antropologia pragmatyczna zdaniem Kanta - jest częścią filozofii, i to częścią normatywną.

Dokonując tego rozróżnienia, Kant pozostawał w zgodzie zarówno z założeniami swojej filozofii transcendentalnej, jak i z tradycją, która nakazywała rozdzielać te dwie, różniące się metodą i przedmiotem, sfery refleksji. Nie ulegało dla niego wątpliwości, że dla filozoficznej koncepcji człowieka ważna jest analiza postępków, „poprzez które manifestuje on swój charakter", a nie "porównanie jego szkieletu ze szkieletami innych gatunków zwierząt"'.

Dwa wieki później antropologia filozoficzna wybrała inną drogę ścisła współpraca z przyrodoznawstwem stała się elementem jej progra-

3 Mimo popularnej formuły wykładu Kant nie rezygnuje $\mathrm{w}$ tej dziedzinie $\mathrm{z}$ ambicji naukowych. W liście napisanym pod koniec 1773 roku do Marcusa Herza podkreśla, że zamierza uczynić z antropologii porządną dyscyplinę akademicką. I. Kant, Encyklopedia filozoficzna, przeł. A. Banaszkiewicz, Aureus, Kraków 2003, s. 152.

4 W 1799 roku krytyczną recenzję Antropologii opublikował Friedrich Schleiermacher. Zob. Athenaeum 2, s. 300-306.

5 I. Kant, Antropologia w ujęciu pragmatycznym, przeł. E. Drzazgowska, P. Sosnowska, Wydawnictwo IFiS PAN, Warszawa 2005, s. 1.

6 I. Kant, Recenzja Myśli o filozofii dziejów J.G. Herdera, przekł. zbiorowy, w: idem, Rozprawy z filozofii historii, przekł. zbiorowy, Wydawnictwo ANTYK, Kęty 2005, s. 60. 
mu. Wykluczając badania przyrodnicze z obszaru zainteresowań filozofii, Kant nie był jednak do końca konsekwentny. Opisując hipotetyczną genezę człowieka, odwoływał się do wiedzy zgromadzonej przez nauki szczegółowe, których dokonania były mu dobrze znane. Jego koncepcja człowieka, naszkicowana w Antropologii i innych pracach, nie ma jednak charakteru empirycznego, opiera się na racjonalnej intuicji i logice właściwej Krytykom.

Kant przyjmuje w niej, że natura wyposażyła człowieka w zdolność samodoskonalenia się. Jej najważniejszym rezultatem jest postęp na drodze rozumności i samoświadomości. Człowiek rodzi się bowiem jako animal rationabile, czyli istota potencjalnie rozumna i dopiero dzięki własnej aktywności oraz pomocy innych ludzi (wychowanie) rozwija dane mu przez naturę zadatki i pokonuje kolejne przeszkody na drodze do rozumności (animal rationale).

Wydarzeniem przełomowym $\mathrm{w}$ procesie samodoskonalenia człowieka jest wyłonienie się refleksyjnej świadomości:

Człowiek dzięki temu, że może mieć przedstawienie swego ja, wyniesiony jest nieskończenie wysoko ponad wszystkie inne żyjące na ziemi istoty. Za sprawą tego jest on osoba, a jedność jego świadomości powoduje, że przy wszystkich zmianach, jakie mogą go spotkać, pozostaje jedną i tą samą osobą. Ze względu na swą rangę i godność jest więc istotą całkowicie różną od rzeczy, a także od równych im, pozbawionych rozumu zwierząt, którymi można rozporządzać wedle upodobania ${ }^{7}$.

Choć byt cielesny, określony przez fizyczno-biologiczne właściwości organizmu, wiąże człowieka ze światem przyrody, to jego byt duchowy, byt osoby, konstytuowany bezpośrednio przez samoświadomość, uwalnia go od presji popędów i zwierzęcych skłonności - czyni go wolnym. Człowiek staje się w pełni człowiekiem dopiero jako byt osobowy - to kluczowa teza racjonalistycznej antropologii Kanta.

Określona postać cielesności odróżnia człowieka od innych istot żywych, ale nie czyni go jeszcze wyjątkowym. Dopiero sfera ducha, której tożsamość nie opiera się na tożsamości substancji, lecz na tożsamości samowiedzy, wyróżnia go jakościowo na tle świata zwierząt. Jako osoba człowiek zyskuje szczególną wartość wewnętrzną, godność, staje się podmiotem moralności. Ten ostatni aspekt jest dla Kanta szczególnie ważny, gdyż - jak zauważa - samo „posiadanie rozumu [...]wcale nie podnosi człowieka $\mathrm{w}$ wartości ponad [...] zwierzęcość, jeśli rozum ten ma mu służyć tylko do tego, co u zwierząt spełnia instynkt" ${ }^{\prime \prime}$. Gdy jed-

7 I. Kant, Antropologia w ujęciu pragmatycznym, op. cit., s. 9.

8 I. Kant, Krytyka praktycznego rozumu, przeł. J. Gałecki, PWN, Warszawa 1984, s. 103 . 
nak wykorzystuje on rozum także do wyższego celu, mianowicie „by to, co jest samo w sobie dobre albo złe" uczynić naczelnym warunkiem swego postępowania, człowiek wznosi się na wyższy poziom egzystencji, działa z szacunku dla prawa moralnego.

Kant nie ukrywa, że interesuje go przede wszystkim człowiek , jako taki”, a nie jego historyczne „wcielenia” czy też „manifestacje” - reprezentuje stanowisko esencjalistyczne. Jeśli „istota to pewne stałe, konstytutywne elementy w bycie, decydujące o jego tożsamości i kwalifikacji rodzajowo-gatunkowej"9, to tym, co w człowieku zasadnicze, co go wyróżnia w świecie istot żywych, jest - według Kanta - reprezentowana przez niego rozumność (animal rationale) i moralna podmiotowość. Nie jest to jednak esencjalizm substancjalistyczny, lecz aktualistyczny - człowiek jest zawsze dopiero w drodze ku swojej istocie („,rosochate drzewo", "aspołeczna towarzyskość", wychowanie), której niedościgłym ideałem jest "czyste jestestwo rozumne", zawsze kierujące się dobrą wola, czyli Bóg. Pełnia bytu człowieka nie należy zatem do jego istoty.

Skończoność osobowego bytu człowieka szczególnie widoczna jest w życiu moralnym: pełnia dobra moralnego nie istnieje w osobie ludzkiej. Nawet najbardziej wartościowy człowiek stanowi jedynie fragmentaryczną manifestację osoby boskiej. Racje esencjalnej strony bytu ludzkiego są zatem wobec niej transcendentne.

\section{Johann Gotffried Herder - poszukiwanie empirycznej koncepcji człowieka}

Johann Gottfried Herder zdobył sławę przede wszystkim jako teoretyk literatury i twórca ważnych koncepcji z dziedziny estetyki. Jego koncepcja człowieka, będąca przykładem owocnej współpracy filozofii z naukami szczegółowymi, została doceniona dopiero w XX wieku. Herder podobnie jak jego nauczyciel Immanuel Kant - mówił o konieczności przewrotu kopernikańskiego w filozofii. Nie wiązał go jednak z teorią poznania, lecz z zadaniem stworzenia spójnej, całościowej koncepcji człowieka.

Herder wybrał drogę, którą już na wstępie odrzucił Kant: badanie człowieka jako istoty biologicznej, cielesnej, funkcjonującej w określonym środowisku przyrodniczym (antropologia fizjologiczna). Punktem wyjścia jego refleksji jest zatem człowiek żyjący i walczący o przetrwanie, a nie - jak u Kanta - poznające i doskonalące się animal rationabile.

Podkreślając znaczenie tego, co przyrodnicze w człowieku, Herder w nowy sposób ujął relacje między światem ludzkim i zwierzęcym.

\footnotetext{
9 W. Stróżewski, Ontologia, Aureus/Znak, Kraków 2004, s. 156.
} 
Rezultat przeprowadzonej przez niego porównawczej analizy był, na pierwszy rzut oka, zaskakujący i rozczarowujący wszystkich tych, którzy gotowi byli widzieć w człowieku najwyższy szczebel rozwoju życia na ziemi.

Sporządzona przez Herdera lista słabości homo sapiens jest długa. Ustępuje on zwierzętom pod względem siły mięśni i zmysłów, pewności instynktów i wrodzonej zręczności, specjalizacji i przystosowania do życia w określonym środowisku; wszystko jest u niego w wielkiej dysproporcji: naturalne wyposażenie i skala potrzeb, siły i zakres działania. Wniosek płynący z tego porównania mógł być tylko jeden: człowiek pod względem biologicznym jest „istotą naznaczoną brakiem"10.

Herder błyskotliwie wyjaśnia wątpliwości związane z ideą Mängelwesen. Jego zdaniem można mówić o brakach w wyposażeniu rodu ludzkiego, gdy za punkt odniesienia i wzór doskonałości przyjmie się zwierzęce wyposażenie i styl życia. Gdy jednak przyjmie się szerszą perspektywę, ocena musi ulec zmianie. Słabość zmysłów okazuje się atutem człowieka - umożliwia rozwój i sprawne funkcjonowanie rozumu. "Gdyby bowiem człowiek miał zmysły zwierząt, to nie miałby rozumu, gdyż ich zbytnia pobudliwość musiałaby zdławić wszelką zimną rozwagę"11. Brak lub rozproszenie instynktów to również czynnik umożliwiający istnienie rozumu. „Jeżeli człowiek miałby instynkty zwierząt, nie mógłby mieć tego, co teraz nazywamy w nim rozumem; instynkty te bowiem w tak niejasny sposób skierowałyby jego siły na jeden punkt, że nie miałby żadnego swobodnego pola do refleksji"12.

Dzięki słabości zmysłów człowiek zyskuje także wolność. W świecie przyrody obowiązuje bowiem prawidłowość: im bardziej wyostrzone są zmysły, tym mniejszy jest krag ich zadań; im słabsze są zmysły danego gatunku, tym większy jest świat, który jest dla niego dostępny. Człowiek dzięki „niedoskonałości” swoich zmysłów nie jest skazany na funkcjonowanie $\mathrm{w}$ ściśle określonym środowisku, lecz może zasiedlać cały świat, "wszędzie czuje się jak u siebie w domu”"13.

10 Herder nie posługiwał się, wprowadzonym dopiero przez Gehlena, terminem Mängelwesen („istota naznaczona brakiem”). Jednak, jak zauważa sam Gehlen, to właśnie Herder jako pierwszy z całą wyrazistością "definiert den Menschen als Mängelwesen". A. Gehlen, Der Mensch, 7. Auflage, Athenäum Verlag, Frakfurt am Main-Bonn, s. 83. Literatura dotycząca rezultatów dokonanej przez Herdera konfrontacji jest obszerna. Zob. np. E. Adler, Herder i oświecenie niemieckie, PWN, Warszawa 1964; H. D. Irmscher, Johann Gottfried Herder, Ph. Reclam jun., Stuttgart 2001.

11 J. G. Herder, Rozprawa o pochodzeniu jezyka, przeł. B. Płaczkowska, w: J. G. Herder, Wybór pism, wyb. i oprac. T. Namowicz, przeł. J. Gałecki i in., Zakład Narodowy im. Ossolińskich, Wrocław 1987, s. 83.

12 Ibidem, s. 83.

13 Ibidem, s. 158. 
Przyjęta przez Herdera zasada komplementarności (warunkiem rozwoju pewnych potencjalnych możliwości jest osłabienie innych, które je hamują ${ }^{14}$ ) pozwala mu inaczej, niż czyniono w jego czasach, spojrzeć na problem swoistości człowieka. W epoce, która skupiała swoją uwagę prawie wyłącznie na rozumnym aspekcie istnienia człowieka, Herder postrzega go jako całość obejmującą zarówno duchowa jak i cielesno-zmysłową sferę egzystencji. Całość ta określana jest przez niego (trudnym do przetłumaczenia ${ }^{15}$ ) terminem Besonnenheit. Składają się na nią dane człowiekowi talenty i siły, zmysły i instynkty, zdolność mówienia i samodoskonalenia się, ciało i duch. Wszystko to razem - zdaniem Herdera - tworzy skomplikowany system wzajemnie przenikających i warunkujących się czynników, decydujących o wyjątkowości człowieka.

Złożona struktura przestrzeni tego, co ludzkie (Besonnenheit), ma według Herdera - punkty węzłowe, które widoczne są w każdej, historycznie zmiennej postaci człowieczeństwa. Wśród nich na pierwszy plan wybija się język pozwalający identyfikować i nazywać nie tylko rzeczy, lecz także siły i zjawiska otaczającego nas świata. Dzięki temu stają się one jego sprzymierzeńcami, możliwe jest odciążenie człowieka.

Język umożliwia kumulatywny rozwój gatunku ludzkiego, postęp nieznany światu zwierzęcemu ${ }^{16}$. Odgrywa też kluczową rolę $\mathrm{w}$ procesie socjalizacji człowieka - zarówno wtedy, gdy uczy się on mówić i cho-

14 Zasadę rozwoju świata organicznego ustalającą istnienie odwrotnie proporcjonalnej relacji między ostrością zmysłów i określonością instynktów a wielkością i zróżnicowaniem środowiska, w którym funkcjonuje dany organizm, potwierdziły badania prowadzone przez niemieckiego biologa i etologa Jacoba Johanna von Uexkülla (1864-1944); zob. idem, Umwelt und Innenwelt der Tiere (1909).

15 Barbara Płaczkowska proponuje, aby termin Besonnenheit rozumieć jako „rozwagę", , "ponieważ splata się w nim podwójne znaczenie słowa Sinn jako 'sens', 'czynność intelektualna' oraz 'zmysł'. Konotacją terminu „rozwaga” jest więc połączenie rozumu i zmysłów”. Zob. przypis tłumacza, w: J. G. Herder, Wybór pism, op. cit., s. 84. Emil Adler, autor pierwszej polskiej monografii poświęconej życiu i twórczości Herdera, tłumaczy „Besonnenheit” jako „rozum” (,refleksję”), który rozwija się wraz z mową. Zob. E. Adler, Herder i oświecenie niemieckie, op. cit., s. 129. Z kolei Andrzej Przyłębski traktuje "Besonnenheit” jako „związaną z językiem refleksyjność”. Zob. A. Przyłębski, Herder jako pionier filozofii życia (www.przylebski.com/pdf/herder jako pionier filozofii życia.pdf), s. 6. Wydaje się, że propozycje ww. autorów zbyt wąsko ujmują sens terminu Besonnenheit. W Abhandlung über den Ursprung der Sprache Herder stwierdza bowiem wprost, że „nie każda aktywność duszy jest bezpośrednim następstwem namysłu, zastanowienia się, refleksji (Besinnung); każda jednakże jest następstwem Besonnenheit". J. G. Herder, Abhandlung über den Ursprung der Sprache, hrsg. von H. D. Irmscher, Ph. Reclam jun., Stuttgart 2001, s. 85. W przedstawionej pracy rozumiem Besonnenheit jako „przestrzeń możliwości człowieczeństwa”.

16 Język jest „skarbnicą myśli ludzkich, do której każdy na swój sposób coś wnosił. Sumą aktywności wszystkich ludzi". J. G. Herder, Rozprawa o pochodzeniu języka, op. cit., s. 166. 
dzić, gdy „pobudzana jest aktywność jego uczuć i myśli”, jak i wtedy, gdy współpracuje z innymi ludźmi, walcząc o przetrwanie i lepszy byt.

\section{Kant a współczesna filozofia człowieka}

Przyjmując perspektywę współczesnych dyskusji o człowieku, można postawić pytanie o aktualność antropologicznych rozważań Kanta: czy mogą być jeszcze źródłem inspiracji?; czy jego argumenty i styl myślenia o człowieku nie zestarzały się nadmiernie?

Kant jest przywoływany przez tych wszystkich, którym bliska jest koncepcja człowieka jako istoty rozumnej. Po dekadach kwestionowania idei animal rationale (Nietzsche, psychoanaliza, nauki szczegółowe), krytyce często zasłużonej, lecz może zbyt daleko idącej ${ }^{17}$, wyraźnie widoczny jest renesans zainteresowania rozumnościa, traktowaną jako element konstytutywny człowieczeństwa ${ }^{18}$. Zasadniczą przesłanką prób rehabilitacji koncepcji człowieka jako istoty rozumnej jest przekonanie, że „W obrębie naszego gatunku rationalitas i humanitas są nieoddzielne"19, podważanie zaś za pomocą rozumu rozumności gatunku ludzkiego prowadzi w pułapkę circulus vitiosus.

Zdecydowanie mniej oczywistym powodem odwoływania się do Kanta jest przekonanie o potrzebie budowy takiej koncepcji człowieka, która ujmuje go na scenie życia w jak najszerszym kontekście, uwzględniającym również metafizyczny horyzont jego egzystencji.

Zapowiedź takiego ujęcia człowieka przez Kanta dostrzec można już w jego "czterech pytaniach". Gerd Haeffner interpretuje je następująco: „pierwsze trzy pytania mają swe źródło w zainteresowaniu człowieka zgłębieniem swojej własnej istoty", zaś

rozstrzygającym krokiem, który prowadzi do poznania siebie samego, jest objaśnienie tych trzech pytań i udzielenie na nie odpowiedzi. Gdy się to ma już za sobą - a dokonuje się to najpierw w stawianiu pytań metafizycznych, etycznych i religijnych, a dopiero potem $\mathrm{w}$ antropolo-

17 Idea animal rationale kreuje wizję człowieka uwolnionego od cielesności, emocji i tradycyjnych form życia, istoty, która jest czysta, samoweryfikującą się racjonalnością. Nawet jeśli ten typ myślenia nie przystaje do przedmiotu, to „można go uznać za osiągnięcie warte zachodu dla pewnych celów; coś, na co czasem potrafimy się zdobyć, nawet jeśli ze swojej natury nasza myśl jest ucieleśniona, dialogiczna, przesiąknięta emocjami i odzwierciedla założenia naszej kultury". Ch. Taylor, Etyka autentyczności, przeł. A. Pawelec, Wydawnictwo Znak, Kraków 2002, s. 97-98.

18 Zob. P. Berger, A. Zijderveld, Pochwała watpliwości, przeł. S. Baranowski, vis-avis/Etiuda, Kraków 2015; H. Schnädelbach, Próba rehabilitacji „animal rationale”, przeł. K. Krzemieniowa, Oficyna Naukowa, Warszawa 2001.

19 H. Schnädelbach, Próba rehabilitacji „animal rationale”, op. cit., s. 3. 
gii - wtedy zna się najważniejszy element odpowiedzi na pytanie: Czym jest człowiek?20.

Historia recepcji filozofii Kanta pokazuje, że problem metafizyki w jego twórczości to skomplikowane zagadnienie. Na przełomie XVIII i XIX wieku był on postrzegany jako odnowiciel metafizyki ${ }^{21}$. W drugiej połowie XIX wieku popularność zdobył pogląd, że główną zasługą Kanta było ugruntowanie doświadczenia i destrukcja metafizyki (H. Helmholtz, K. Fischer, E. Zeller). Pogląd ten, propagowany przez wybitnych przedstawicieli różnych nurtów neokantyzmu (H. Cohen, P. Natorp, F. A. Lange, A. Riehl), dominował w interpretacji filozofii Kanta aż do schyłku XIX wieku.

Na przełomie XIX i XX wieku za sprawą Friedricha Paulsena (metafizyka jest kulminacją Kantowskiego systemu ${ }^{22}$, Hansa Vaihingera (w filozofii Kanta wyraźnie widoczny jest system poglądów metafizycznych, które mają status podobny do platońskiego mitu o stworzeniu świata) ${ }^{23}$ i Konstantina Oesterreicha (u Kanta istnieją dwa rodzaje metafizyki: metafizyka immanentna oraz krytyczna metafizyka tego, co transcendentne $)^{24}$ ponownie zostało postawione pytanie o status metafizyki w filozofii Kanta. Stopniowo przekonanie o ważnej roli metafizyki w filozofii Kanta zaczęło się upowszechniać. Ważną rolę w tym procesie odegrały dzieła Aloisa Riehla (Der philosophische Kritizismus, 1924), Ericha Adickesa (Kants Opus postumum, 1920), Maxa Wundta (Kant als Metaphysiker, 1924) i Martina Heideggera (Kant und das Problem der Metaphysik, 1929).

Ujmując Kanta w kategoriach metafizyki, przywołuje się wiele argumentów. Nie sposób odnieść się do wszystkich. Jedna z możliwości polega na przyjęciu jako punktu wyjścia wyrażonej przez niego opinii, że metafizyka ",jako wrodzona skłonność (metaphysica naturalis)" istniała, istnieje i istnieć będzie zawsze ${ }^{25}$. Zdaniem Kanta rozum ludzki, gdy tylko dojrzeje do spekulacji, nieustannie stawia pytania dotyczące transcendencji, mające zaspokoić jego naturalne potrzeby. Jest wprawdzie dowiedzione, że naukowa wiedza o bytach transcendentnych (Bóg,

20 G. Haeffner, Wprowadzenie do antropologii filozoficznej, przeł. W. Szymona OP, WAM, Kraków 2006, s. 20.

${ }^{21}$ Jego dzieła przyczyniły się do rozwoju badań metafizycznych w Niemczech, a sprawcy tego ożywienia: Johann Gottlieb Fichte, Georg Wilhelm Hegel, Friedrich Wilhelm Schelling i Artur Schopenhauer byli wdzięczni Kantowi za to, że otworzył im oczy na ponadzmysłowy świat.

${ }^{22}$ Immanuel Kant. Sein Leben und seine Lehre (1898).

${ }^{23}$ Kant-ein Metaphysiker? (1900).

${ }^{24}$ Kant und die Metaphysik (1906). Kilka lat później na polskim gruncie podobnie interpretuje Kanta Mścisław Wartenberg. Zob. idem, O Krytyce praktycznego rozumu i jej stosunku do Krytyki czystego rozumu (1910).

25 I. Kant, Krytyka czystego rozumu, przeł. R. Ingarden, Wydawnictwo Antyk, Kęty 2001, s. 65 (B21). 
dusza, wszechświat jako całość) jest niemożliwa, gdyż w odniesieniu do tych przedmiotów poznania nie istnieje ani empiryczna, ani czysta naoczność. Krytyka czystego rozumu teoretycznego przygotowuje jednak miejsce dla praktycznego użycia rozumu. Dopiero po odebraniu rozumowi spekulatywnemu jego "roszczenia do przesadnych poznań" możliwy staje się powrót do problematyki metaphysica specialis ${ }^{26}$ - na gruncie rozumu praktycznego uzasadnione zostają: wolność jako warunek możliwości tego, co moralnie pożądane; nieśmiertelność duszy jako podstawa nieskończonego procesu moralnego doskonalenia się; Bóg jako istota gwarantująca harmonię między moralnością i szczęśliwością.

Kantowska metafizyka ma ważność praktyczną, nie rości sobie pretensji do statusu poznania teoretycznego. Należy jednak pamiętać o konsekwencjach prymatu rozumu praktycznego - tam, gdzie władza rozumu teoretycznego nie wystarcza do ustalenia pewnych tez, musi on je przyjąć ze względu na autorytet władzy wyższej, czyli rozumu praktycznego. Taki jest właśnie stosunek między Kantowską praktyczną metafizyką i jego teoretyczną krytyką metafizyki ${ }^{27}$.

W Kantowskiej koncepcji człowieka, mimo jej wyraźnie egologicznego charakteru, widoczne jest (szczególnie w dziełach późnego okresu) przekonanie, że człowiek ujęty w całej swojej złożoności (z jednej strony - dane mu talenty, uzdolnienia i zdolność samodoskonalenia, z drugiej zaś - słabości ciała, psychiki, woli i umysłu) może być zrozumiany dopiero wtedy, gdy spojrzy się na niego z szerszej perspektywy uwzględniającej ontyczny porządek świata i eschatologiczny wymiar jego istnienia ${ }^{28}$. Teleologiczna wizja otwartego na świat, samodoskonalącego się człowieka i podążającego drogą postępu gatunku ludzkiego wymaga - według Kanta - dopełnienia postulatami czystego rozumu praktycznego. Egzystencja człowieka zostaje tym samym wzbogacona o aspekt metafizyczny, staje się w pełni zrozumiała w obliczu (postulatywnie ujmowanej) transcendencji ${ }^{29}$.

26 Zob. ibidem, s. 42 (BXXX).

27 Zob. J. Disse, Metafizyka. Od Platona do Hegla, przeł. L. Kusak i A. Węgrzecki, WAM, Kraków 2005, s. 247.

28 Już Kantowskie „cztery pytania” wskazuja, że przyjęty przez niego porządek myśli prowadzi od poznania świata do poznania człowieka. Jest to droga, którą później podążał również Nietzsche. Starożytność, począwszy od Heraklita, wybrała odmienne rozwiązanie. Koncentrowała się na poznaniu człowieka, traktując je jako klucz do tajemnic bytu.

${ }^{29}$ W tym samym kierunku, choć inną droga, podążał - znajdując się po części pod wpływem Kanta - Edmund Husserl. Roman Ingarden ujął to następująco: „W ostatecznym rachunku szukał drogi do Boga jako do najwyższego absolutnego rozumu, w którym spodziewał się znaleźć swe własne udoskonalenie i ostateczny spokój, do Boga, który miał być podstawą teologii czystej świadomości". R. Ingarden, Z badań nad filozofią wspótczesna, PWN, Warszawa 1963, s. 627. 
Nie jest rzeczą oczywistą pogląd, że metafizyczne zakorzenienie Kantowskiej koncepcji człowieka - w naszych czasach - może być traktowane jako atut, a nie przejaw intelektualnej słabości. Filozofowie i szkoły filozoficzne odżegnujące się od jakichkolwiek związków z metafizyką stanowią silny nurt współczesnej refleksji antropologicznej. Autorowi bliskie jest jednak stanowisko tych, którzy nie podzielają opinii o archaiczności takiego mariażu (M. Scheler, M. Heidegger, K. Jaspers, M. Buber, N. Hartmann, K. Barth, R. Bultmann, Ch. Taylor). Reprezentatywna dla nich jest wypowiedź Maxa Schelera. Wyraża on przekonanie, że metafizyka uprawiana rzetelnie oznacza dla człowieka „uniezależnienie się, wyzwolenie się od trwogi, od naporu nagiej „egzystencji”, od przypadkowości losu", jest więc ona

tym, czym była dla Platona, Arystotelesa, Spinozy, Kanta: swobodnym oddechem człowieka, któremu grozi uduszenie we własnym, specyficznym "otoczeniu". Zachód zagubił już prawie całkowicie ideę metafizyki, a tym bardziej jej techniki i metodykę poznawcza, stłumioną zupełnie w zgrzebnej wierze w dogmaty Kościoła oraz w pozytywnej, nastawionej na osiagnięcia nauce specjalistycznej. Izolowanie, odgradzanie człowieka od jego bezpośredniego, egzystencjalnego i życiowego kontaktu z zasadą wszechrzeczy oznacza takie samo straszliwe zacieśnienie [horyzontów] człowieka [...], jakim, z drugiej strony, jest odgrodzenie człowieka od przyrody. Człowiek, powiada Goethe, potrzebuje trzech [rodzajów] czci: w obliczu tego, co znajduje się ponad nim, poniżej i obok niego ${ }^{30}$.

\section{Herder a współczesna filozofia człowieka}

Biorąc pod uwagę wyzwania, przed którymi stoi współczesna filozofia, zasadne jest pytanie o aktualność antropologicznego dorobku Herdera. $\mathrm{Na}$ gruncie filozofii człowieka autor Rozprawy o pochodzeniu języka był prekursorem porównawczych badań, w których zwierzęcość stanowiła ważne kategorialne odniesienie samozrozumienia gatunku ludzkiego. Choć mogłoby się wydawać, że idea Mängelwesen i analiza odwołująca się do opozycji „,człowiek - zwierzę”, wyczerpały już swoją heurystyczną siłę, to jednak przykład współczesnej, naturalistycznie zorientowanej filozofii wydaje się temu przeczyć. Również filozofowie odżegnujący się od przyrodniczego redukcjonizmu traktują je jako wygodny dla swoich wywodów punkt odniesienia, nie tylko w znaczeniu negatywnym, lecz także pozytywnym.

30 M. Scheler, Człowiek w epoce zacierania się przeciwieństw, przeł. S. Czerniak, w: idem, Pisma z antropologii filozoficznej i teorii wiedzy, przeł. S. Czerniak i A. Węgrzecki, PWN, Warszawa 1987, s. 224-225. 
Szukając idei, która mogłaby być źródłem inspiracji dla współczesnej, filozoficznej refleksji nad człowiekiem, warto jednak sięgnąć przede wszystkim do Herderowskiej kategorii Besonnenheit. Ma ona bowiem godny uwagi potencjał - umożliwia spojrzenie na toczone od wieków spory z dalszej perspektywy, przełamuje utarte schematy i rzuca nowe światło na problematykę antropologiczną.

W słowniku pojęć Herdera kategoria ta odgrywa kluczową rolę. Wyraża ona swoistość człowieka, która - w stosunku do świata zwierzęcego - nie polega na różnicy poziomu czy stopnia, lecz na „zupełnie odmiennym kierunku i rozwoju wszystkich sił"(ganz verschiedenartigen Richtung und Auswickelung aller Kräfte) ${ }^{31}$. Nie chodzi tu zatem o kompensację braków naturalnego wyposażenia, o taką czy inną skłonność, talent czy cechę, lecz o całość powiązanych ze sobą w niepowtarzalną strukturę duchowych i cielesnych, konstytutywnych elementów ludzkiego istnienia ${ }^{32}$.

Struktury tej nie da się precyzyjnie opisać. Żaden z konstytuujących ją elementów nie może być uznany za istotę człowieka.

Filozoficzną bzdurą jest pogląd, że rozum ludzki wniknął do duszy jako zupełnie nowa, odrębna siła, uzupełnienie wyróżniające go od wszystkich zwierząt [...]. Wszystkie siły naszych i zwierzęcych dusz są niczym innym jak filozoficznymi abstrakcjami. Są one podzielone, ponieważ nasz słaby umysł nie może ich naraz ogarnąć [...]. To, że pewnym ich czynnościom przydaliśmy pewne nazwy, jak np. rozum, bystrość, fantazja, rozsądek nie oznacza wcale, że możliwa byłaby jedna jedyna czynność ducha, gdzie działa sam rozum czy rozsądek. Jeśli człowiek kiedykolwiek mógłby wykonać jakąś jedną jedyną czynność, podczas której myślałby całkowicie jak zwierzę, nie byłby już absolutnie człowiekiem [...], chyba, że zmieniłaby się cała jego dusza, cała jego natura ${ }^{33}$.

Tradycyjne wyróżniki człowieczeństwa (duch, rozum, zdolność samodoskonalenia, świadomość, wyobraźnia, wolność, moralność, język), same w sobie nie stanowią jeszcze o wyjątkowości homo sapiens. Dopiero wszystkie razem, powiązane ze ściśle określonymi predyspozycjami cielesnymi (Organisation des Körpers), decydują - zdaniem Herdera - o zasadniczo odmiennym, w porównaniu do zwierzęcego, sposobie istnienia człowieka. Ta odmienność nie ma charakteru ilościowego, lecz jakościowy: „gatunek ludzki góruje nad zwierzętami

31 J. G. Herder, Rozprawa o pochodzeniu języka, op. cit., s. 82.

32 Herder odrzuca warstwową koncepcję człowieka. Człowieczeństwo - jego zdaniem - nie jest jakąś dodatkową warstwą "dołożoną" do warstw zwierzęcych, lecz jest obecne w każdym elemencie ludzkiego istnienia, zarówno w tym, co materialne, jak i w tym, co duchowe, we wszystkim ujawnia się natura innego rodzaju niż natura zwierzęca.

33 J. G. Herder, Rozprawa o pochodzeniu języka, op. cit., s. 83. 
nie pod względem szczebli tego, czego więcej czy mniej, lecz pod względem rodzaju (Art.)" ${ }^{\prime 34}$.

Herder podkreśla, że odmienność istoty ludzkiej widoczna jest już od momentu jej narodzin. Wprawdzie dane jej talenty i predyspozycje pozostają jeszcze $w$ uśpieniu ${ }^{35}$, jednak od samego początku jest ona człowiekiem, a nie pozbawioną tożsamości żywą istotą: od pierwszego momentu budzi się we wszechświecie nie zwierzę, lecz otwarty na świat człowiek, jeszcze nie stworzenie myślące (Geschöpf von Besinnung), ale już reprezentujące sobą zupełnie nową jakość istnienia, określaną terminem Besonnenheit ${ }^{36}$.

Herder nie neguje swoistej niepowtarzalności jednostek, które reprezentują sobą bezkresną paletę możliwych form artykulacji życia, akcent kładzie jednak na to, co wspólne, co łączy wszystkich ludzi. Pod tym względem można by uznać go za prekursora idei rozwijanych $\mathrm{w}$ antropologii fundamentalnej Michaela Landmanna ${ }^{37}$. Zależy mu bowiem na pogodzeniu dwóch, traktowanych jako opozycyjne, stanowisk - tego, które podkreśla wielość historycznych wcieleń człowieka, płynny charakter jego egzystencji, z tym, które odwołuje się do ponadczasowych, antropologicznych „powszechników”. Dziejowość człowieka - według Herdera - nie wyklucza istnienia stałych wyznaczników, zarówno wewnętrznej konstytucji, jak i zewnętrznej przestrzeni jego egzystencji.

Rozróżnienie między tym, co historyczne i tym, co ponadczasowe w człowieku nie musi zatem prowadzić do nierozstrzygalnego sporu. Człowieczeństwo jest nam dane i zarazem zadane - to przestrzeń możliwości, które realizują się w historii. Jako całość jest to zbiór nieskończony. Czynnikiem stabilizującym tę przestrzeń, niezmiennymi ramami

34 Ibidem, s. 81. Myśl tę w dosłownym brzmieniu zaczerpnął Herder od niemieckiego teologa i filozofa Hermanna Samuela Reimarusa (1694-1768). Podaję za: H. D. Irmscher, Nachwort, w: J. G. Herder, Abhandlung..., op. cit., s. 150.

35 Podobnie jak Kant, Herder kładzie duży nacisk na rozwój człowieka. Początkowo główną rolę odgrywa w nim środowisko społeczne, inni członkowie jego gatunku, którzy go chronia, żywią i uczą. Proces wychowania stopniowo coraz bardziej wspierany jest przez własny wysiłek jednostki, która rozwija dane jej zadatki i talenty, wyznaczając swoją niepowtarzalną ścieżkę życia. „A więc nigdy nie cały człowiek, lecz zawsze rozwijający się, posuwający się dalej, doskonalący się. [...] Nigdy istotą naszego życia nie jest używanie, lecz zawsze progresja i nigdy nie jesteśmy ludźmi, dopóki nie przeżyliśmy życia do końca". G. Herder, Rozprawa o pochodzeniu jezzyka, op. cit., s. 138.

${ }^{36}$ Zob. J. G. Herder, Abhandlung..., op. cit., s. 82. Wyraźnie widoczna jest tu polemika Herdera z J. J. Rousseau, dla którego człowiek w swym początkowym stadium rozwoju był „dziką istotą", bardziej zwierzęciem niż człowiekiem.

37 M. Landmann, Fundamental-Anthropologie, Bouvier Verlag Herbert Grundmann, Bonn 1979. 
ludzkiego istnienia są antropologiczne powszechniki, anthropina, wypełniane właściwą dla danej epoki i kulturowego kontekstu treścią ${ }^{38}$.

Człowieczeństwo - w ujęciu Herdera - to zatem swoista coincidentia opositorum; to, co wspólne, uniwersalne, ponadczasowe, „ściera się" w nim z tym, co jednostkowe, niepowtarzalne, historyczne; próby "zamknięcia” homo sapiens w sztywnych ramach systemów i kategorii budzą niedosyt i opór, ze względu na „niewyczerpywalny” i „niezgłębialny" charakter ludzkiego życia. Najwyższą formą poznania byłaby jednak synteza, poznawcze połączenie tych przeciwieństw w jedność, którą wydają się one tworzyć. Emblematycznym symbolem wielości i jedności zarazem jest - w koncepcji Herdera - kategoria Besonnenheit.

\section{Uwagi końcowe}

Patrząc przez pryzmat koncepcji Maxa Schelera, Helmutha Plessnera i Arnolda Gehlena, stosunkowo łatwo można wskazać idee, które w filozofii Kanta i Herdera były zapowiedzią nowej dyscypliny zajmującej się człowiekiem - antropologii filozoficznej. Dla oceny znaczenia myśli Kanta i Herdera nie jest jednak kwestią najistotniejszą to, że została ona przez następne generacje filozofów w pewnym zakresie przyjęta i wzbogacona, $\mathrm{w}$ innym zaś - zakwestionowana i odrzucona ${ }^{39}$. Taka jest naturalna kolej rzeczy, nie tylko w filozofii. Ich ważną zasługa, często niedoceniana, jest rozwinięcie instrumentarium pojęciowego i sformułowanie nowych pytań dotyczących człowieka. Dzięki temu można było spojrzeć na problematykę antropologiczną z innego punktu widzenia, otwarła się przestrzeń rozważań, dla której wcześniej brakowało języka.

Powrót do przeszłości bywa niekiedy traktowany jako świadectwo wyczerpywania się sił życiowych, nostalgii, marazmu, kapitulacji wobec wyzwań współczesności. Sięganie do historii nie musi jednak mieć charakteru „antykwarskiego”, może zaś polegać na krytycznej weryfikacji

38 Z punktu widzenia Herdera rację mają zatem zarówno ci, którzy twierdza, że pytanie o swoistość człowieka jest pytaniem otwartym, gdyż jest on nieustannie w drodze do swojego człowieczeństwa („,nigdy nie jesteśmy ludźmi, dopóki nie przeżyliśmy życia do końca", Herder), jak i ci, którzy odwołują się do mocno ugruntowanego w filozofii i w świadomości potocznej przekonania, że w heraklitejskim świecie zmian i różnorodności wyraźnie zarysowuje się struktura bytowa, która pozwala odróżnić go od istot, które ludźmi nie są i nigdy nie będą. Droga do jedności prowadzi zatem przez wielość.

39 Kanta i Herdera koncepcje człowieka zakładają autonomię i źródłowość świadomości egotycznej; cechuje je nastawienie monologiczne - Ty jest uprzedmiotowiane i konstytuowane jako alter ego. Dwudziestowieczna filozofia dialogu zakwestionowała monopol poznającego Ja, wskazując na fundamentalną rolę spotkania i relacji Ja-Ty. 
pojęć i idei, które w minionych epokach zaprzątały umysły filozofów, pod kątem ich przydatności we współczesnym dyskursie filozoficznym. Wybór Kanta i Herdera, jako punktu odniesienia dla współczesnych dyskusji o człowieku, jest do pewnego stopnia subiektywny - odzwierciedla bowiem zainteresowania i preferencje autora artykułu. Przemawiaja za nim jednak argumenty o charakterze obiektywnym. Animal rationale i „człowiek metafizyczny”, Mängelwesen i Besonnenheit to pojęcia, które wzbogacone siłą monopoli oraz "stanów antropologicznych", eksponują różnorodność rzeczywistości człowieka, jego naturę i historyczne zakorzenienie, bogactwo doświadczeń i odpowiadających im perspektyw, nie zamykając zarazem drogi do całościowej jego koncepcji.

Kanta i Herdera różni styl, metoda, jak i kluczowe kategorie. Mimo to można ich koncepcje potraktować jako elementy tego samego, wielowymiarowego obrazu, malowanego od czasów Sokratesa. Łączy je w wielobarwną całość idea człowieczeństwa rozumianego jako przestrzeń możliwości urzeczywistniających się w czasie. Dzięki niej z chaosu przypisywanych człowiekowi atrybutów i własności wyłaniają się kontury postaci, obraz - choć nieostry - staje się czytelny, do pewnego stopnia racjonalny i logiczny. Wieloaspektowa zmienność człowieka nabiera wtedy innego znaczenia, zostaje (na ludzką miarę) okiełznana, historyczne przeobrażenia homo sapiens zyskują (ulotne) piętno stałości.

\section{Bibliografia}

Adler E., Herder i oświecenie niemieckie, PWN, Warszawa 1964.

Berger P., Zijderveld A., Pochwała watpliwości, przeł. S. Baranowski, vis-a-vis/ Etiuda, Kraków 2015.

Brandt R., Kommentar zu Kants Anthropologie, Kant-Forschungen, Bd. 10, Felix Meiner Verlag, Hamburg 1999.

Disse J., Metafizyka. Od Platona do Hegla, przeł. L. Kusak i A. Węgrzecki, WAM, Kraków 2005.

Herder J. G., Rozprawa o pochodzeniu języka, tłum. B. Płaczkowska, w: J. G. Herder, Wybór pism, wyb. i oprac. T. Namowicz, przeł. J. Gałecki i in., Zakład Narodowy im. Ossolińskich, Wrocław 1987.

Haeffner G., Wprowadzenie do antropologii filozoficznej, przeł. W. Szymona OP, WAM, Kraków 2006.

Irmscher H. D., Johann Gottfried Herder, Ph. Reclam jun., Stuttgart 2001.

Kant I., Krytyka czystego rozumu, przeł. R. Ingarden, Wydawnictwo Antyk, Kęty 2001.

Kant I., Krytyka praktycznego rozumu, przeł. J. Gałecki, PWN, Warszawa 1984.

Kant I., „Recenzja Myśli o filozofii dziejów J.G. Herdera”, przekł. zbiorowy, w: I. Kant, Rozprawy z filozofii historii, przekł. zbiorowy, Wydawnictwo ANTYK, Kęty 2005. 
Kant I., Antropologia w ujęciu pragmatycznym, przeł. E. Drzazgowska, P. Sosnowska, Wydawnictwo IFiS PAN, Warszawa 2005.

Kant I., Logika. Podręcznik do wykładów, przeł. A. Banaszkiewicz, słowo/obraz terytoria, Gdańsk 2005.

Landmann M., Fundamental-Anthropologie, Bouvier Verlag Herbert Grundmann, Bonn 1979.

Scheler M., Człowiek w epoce zacierania sie przeciwieństw, przeł. S. Czerniak, w: idem, Pisma z antropologii filozoficznej i teorii wiedzy, przeł. S. Czerniak i A. Węgrzecki, PWN, Warszawa 1987.

Schnädelbach H., Próba rehabilitacji "animal rationale", przeł. K. Krzemieniowa, Oficyna Naukowa, Warszawa 2001.

Stróżewski W., Ontologia, Aureus/Znak, Kraków 2004.

\section{Streszczenie}

\section{O antropologii filozoficznej w vjęciu historycznym (rozważania na marginesie koncepcji Kanta i Herdera)}

Artykuł przypomina udział Immanuela Kanta i Johanna Gottfrieda Herdera $\mathrm{w}$ rozwoju antropologii filozoficznej. Pierwszy z nich był autorem słynnych „czterech pytań", które definiują przedmiot i zasięg filozoficznej dyscypliny badającej człowieka. Natomiast Herder ze swoją koncepcją człowieka jako istoty ułomnej (Mängelwesen) przyczynił się do rozwoju ściślejszej współpracy między filozofią i naukami przyrodoznawczymi. Kanta i Herdera znaczenie dla antropologii ma nie tylko charakter historyczny. Wydaje się, że niektóre zaproponowane przez nich idee (człowiek w horyzoncie metafizycznym, ludzki gatunek jako przestrzeń możliwości) mogłyby zostać użyte do systematyzacji współczesnych dyskusji na temat człowieka.

Słowa kluczowe: „cztery pytania”, antropologia pragmatyczna, osoba duchowa, Mängelwesen, Besonnenheit, człowiek zdany na odciążenie

\section{Summary}

\section{On philosophical anthropology from the historical perspective (reflections on the margins of Kant's and Herder's conceptions)}

The author recalls Immanuel Kant's and Johann Gottfried Herder's contributions to the development of philosophical anthropology. The former was the author of the famous 'four questions' which defined the subject and rank of a new philosophical discipline studying which studied. Herder, in turn, with his 
conception of man as Mängelwesen, contributed initiating of a close cooperation between philosophy and natural sciences. Kant's and Herder's significance for philosophical anthropology is not only historical. It seems that some of the ideas they developed (man in the horizon of metaphysics, humankind as a space of possibilities) could be used in order to systematise the contemporary discussion about man.

Keywords: 'four questions', pragmatic anthropology, spiritual person, Mängelwesen, Besonnenheit, relieving man 